\title{
PENERAPAN MODEL PEMBELAJARAN PROJECT BASED LEARNING (PjBL) UNTUK MENINGKATKAN HASIL BELAJAR SISWA SEKOLAH DASAR
}

\author{
I Ketut Suardika ${ }^{1}$, Heni $^{2}$, La Anse ${ }^{3}$ \\ ${ }^{1}$ Jurusan Pendidikan Guru Sekolah Dasar, Universitas Halu Oleo \\ Email: iketutsuardika@uho.ac.id \\ 2Jurusan Pendidikan Guru Sekolah Dasar, Universitas Halu Oleo \\ Email: heni@gmail.com \\ ${ }^{3}$ Jurusan Pendidikan Guru Sekolah Dasar, Universitas Halu Oleo \\ Email: Laanse@uho.ac.id
}

\begin{abstract}
Abstrak
Tujuan dari penelitian ini adalah "untuk meningkatkan hasil belajar siswa kelas VB SD Negeri 51 Kendari melalui penerapan model Project Based Learning (PjBL) pada Tema Peristiwa Dalam Kehidupan. Penelitian ini termaksud dalam jenis Penelitian Tindakan Kelas/ Clasroom Acrion Research dengan Prosedur penelitian yaitu: (a) perencanaan, (b) pelaksanaan tindakan, (c) observasi dan evaluasi, dan (d) refleksi. Jenis data yaitu data kualitatif dan data kuantitatif. Data kualitatif diperoleh melalui lembar observasise dangkan data kualitatif melalui tes hasil belajar. Hasil penelitian menunjukkan bahwa siswa yang mencapai ketuntasan belajar pada siklus I berjumlah 18 orang dengan persentase sebesar $64,2 \%$ sedangkan jumlah siswa yang tidak tuntas sebanyak 10 orang dengan persentase sebesar $35,7 \%$. Rata-rata hasil belajar siswa pada siklus I yaitu 71 sedangkan pada siklus II hasil belajar siswa mengalami peningkatan yang terdiri dari 24 orang siswa mendapat nilai tuntas dengan persentase ketuntasan adalah $85,7 \%$, sedangkan jumlah siswa yang tidak tuntas adalah 4 orang dengan persentase sebesar $14,2 \%$. Nilai rata-rata hasil belajar siswa pada siklus II yaitu 77
\end{abstract}

Kata kunci: Model pembelajaran project based learning (PjBL), Hasil belajar

\section{Abstract}

The purpose this research to improve the learning outcomes of class VB students of SD Negeri 51 Kendari through the application of the Project Based Learning (PjBL) model on the theme of events in life. The research type using the Classroom Acrion Research with research procedures, using steps: (a) planning, (b) implementation of action, (c) observation and evaluation, (d) reflection. Types of data are qualitative and quantitative data. Qualitative data were obtained through observation sheets while qualitative data were obtained through learning outcomes tests. The results showed that students who achieved learning completeness in the first cycle were 18 people with a percentage of $64.2 \%$ while the number of students who did not complete was 10 people with a percentage of $35.7 \%$. The average student learning outcomes in cycle I was 71 while in cycle II student learning outcomes increased, consisting of 24 students who got a complete score with a percentage of completeness of $85.7 \%$, while the number of students who did not complete was 4 people with a percentage of $14.2 \%$. The average value of student learning outcomes in cycle II is 77

Keywords: Project based learning model, Learning outcomes 


\section{Pendahuluan}

Pendidikan memiliki peranan yang penting dalam membentuk sumber daya manusia yang cerdas, cakap, kreatif, beriman, dan berakhlak mulia. Sistem pendidikan di Indonesia dijelaskan dengan Undang-undang Nomor 20 tahun 2003 tentang Sistem Pendidikan Nasional pasal 1 bahwa yang dimaksud pendidikan adalah usaha sadar dan terencana untuk mewujudkan suasana belajar dan proses pembelajaran agar siswa mengembangkan potensi dirinya untuk memiliki kekuatan spiritual keagamaan, pengendalian diri, kepribadian, kecerdasan, akhlak mulia, serta keterampilan yang diperlukan oleh dirinya, masyarakat, bangsa dan Negara (Efrimal et al. 2017; Lase, 2019).

Untuk mewujudkan tujuan pendidikan sebagaimana UndangUndang Nomor 20 Tahun 2003 tersebut maka faktor guru memiliki peran yang sangat penting dalam mengembangkan potensi sumber daya manusia yang berkualitas dari proses pembelajaran yang dilakukan (Riyanto, 2014; Susanto, 2014). Oleh sebab itu peran guru sangat menentukan dalam upaya membelajarkan siswa (Kawuri et al. 2019). Secanggih apapun teknologi faktor guru tetap diperlukan dan tidak dapat digantikan oleh teknologi. Karena kualitas pendidikan melalui proses pembelajaran sangat ditentukan oleh guru (Notanubun, 2019).

Realitas proses pembelajaran yang dilakukan oleh sebagian guru masih menggunakan pola pembelajaran yang konvensional, dimana kegiatan proses pembelajaran lebih banyak didominasi oleh guru, sementara siswa hanya pasif mendengarkan informasi dari guru, dengan ceramah sebagai metode utamanya (Kawuri \& Fayanto, 2020). Kondisi pembelajaran yang seperti ini membuat siswa jenuh bahkan bosan mengikuti aktivitas proses pembelajaran yang disampaikan oleh guru (Herawati et al. 2019). Konsekuensi dari proses pembelajaran seperti ini akan berdampak pada hasil belajar siswa.

Berdasarkan hasil observasi dan wawancara mengenai proses pembelajaran di SD Negeri 51 Kendari bersama guru kelas VB ibu Nurlina S.Pd, pada tanggal 27 November 2019 menunjukan bahwa dalam kegiatan pembelajaran dalam kurikulum 2013, guru masih menggunakan metode konvensional yakni metode ceramah dan penugasan, serta model pembelajaran belum bervariasi, guru masih menggunakan model pembelajaran kelompok yaitu kelompok dibagi berdasarkan tempat duduk siswa. Dari hasil dokumen guru kelas VB SD Negeri 51 Kendari tahun ajaran 2018/2019 berupa hasil ulangan tengah semester (UTS) pada Tema Peristiwa Dalam Kehidupan, menunjukkan dari 28 orang siswa hanya 12 siswa atau 42,8\% yang mendapat nilai diatas KKM. sedangkan yang dibawah KKM sebanyak 16 orang atau 57,1\% dengan nilai KKM yaitu 70 . Dimana nilai rata-rata keseluruhan siswa yaitu 65,67. Rendahnya nilai siswa diakibatkan kurangnya aktivitas siswa di dalam kelas.

Menyikapi kondisi tersebut tersebut maka perlu dilakukan upaya untuk memperbaiki dan meningkatkan hasil belajar siswa. Salah satu upaya yang dapat dilakukan untuk memperbaiki dan meningkatkan hasil belajar siswa kelas VB SD Negeri 51 Kendari adalah melalui 
model pembelajaran inovatif, salah satunya adalah model pembelajaran Project Based Learning (PJBL).

Penerapan model Project Based Learning potensial memenuhi tuntutan pembelajaran. Hal ini didasarkan pada suksesnya penerapan Project Based Learning dalam beberapa penelitian terdahulu, diantara yaitu menurut Sunardin (2019) menyimpulkan bahwa model pembelajaran berbasis proyek terbukti dan teruji sebagai model belajar atau pembelajaran yang mampu menumbuhkan kemandirian siswa, khususnya pada pembelajaran yang memungkinkan untuk dilaksanakan kerja proyek. Model ini merupakan salah satu model pembelajaran yang sesuai untuk diterapkan pada kurikulum 2013 dan dapat mengatasi permasalahan secara efektif di dalam kelas Kegiatan belajar akan berjalan efektif jika dijalani dengan perasaan senang dan dorongan untuk berpartisipasi dalam pembelajaran dengan kata lain ada minat untuk belajar (Surya et al. 2018).

Model PjBL merupakan model pembelajaran yang bersifat menyenangkan karena diharapkan dapat merubah cara belajar peserta didik secara mandiri dengan meningkatkan motivasi belajar, meningkatkan kreativitas peserta didik dalam berkarya, memunculkan ide-ide kreatif serta melatih berpikir kritis, dalam menyikapi suatu masalah yang dihadapi di dunia nyata. Dalam model pembelajaran PjBL ini dirancang agar siswa mampu menyelesaikan permasalahan dengan suatu aktivitas proyek, dan dalam kerja proyek ini siswa akan mendapat pengalaman nyata tentang perencanaan suatu proyek (Hapsari \& Airlanda, 2019).
Menurut Sari (2017) project based learning (PjBL) merupakan kegiatan pembelajaran yang melibatkan siswa untuk mengerjakan sebuah proyek yang bermanfaat untuk menyelesaikan permasalahan masyarakat atau lingkungan.

Berdasarkan latar belakang di atas maka penulis akan melakukan penelitian tentang Penerapan Model pembelajaran project based learning (PjBL) Untuk Meningkatkan Hasil Belajar Siswa Kelas VB SD Negeri 51 Kendari Pada Tema Peristiwa Dalam Kehidupan. Tujuan studi ini yaitu menganalisis peranan model pembelajaran project based learning dalam menunjang pembelajaran khususnya dari segi peningkatan hasil belajar pada tingkat sekolah dasar.

\section{Metode Penelitian}

Jenis penelitian yang digunakan dalam penelitian ini adalah penelitian tindakan kelas (PTK). Penelitian Tindakan Kelas (PTK) merupakan terjemahan dari Classroom Action Reaearch, yaitu satu action research yang dilakukan oleh guru di dalam kelasnya sendiri melalui refleksi diri, dengan tujuan untuk memperbaiki kinerjanya sebagai guru, sehingga hasil belajar siswa menjadi meningkat (Jakni, 2017).

Penelitian ini dilaksanakan di SD Negeri 51 Kendari yang dulunya bernama SD Negeri 04 Poasia yang terletak di Jl. Prof. Dr. ABD Rauf Tarimana, Kota Kendari semester genap. Subjek penelitian ini adalah siswa kelas VB SD Negeri 51 Kendari dengan jumlah siswa 28 orang dimana siswa laki-laki sebanyak 16 orang dan siswa 
perempuan sebanyak 12 orang. alasan peneliti dalam memilih kelas VB SD Negeri 51 kendari karena lokasi sekolah yang dapat di jangkau oleh peneliti, dan dikelas VB belum perna dilakukan penelitian tentang Model Pembelajaran Project based learning, serta hasil belajar siswa masih rendah. Faktor yang diteliti pada penelitian ini adalah (1)faktor siswa, (2) Faktor guru dan (3) faktor hasil belajar. Penelitian tindakan kelas ini dilaksanakan dalam 2 (dua) siklus.

Adapun prosedur penelitian ini menggunakan desain Kemmis \& Taggart yang masing-masing terdiri atas tahaptahap: kegiatan (a) perencanaan, (b) pelaksanaan tindakan, (c) observasi dan evaluasi, dan (d) refleksi (Sucipto, 2015) seperti yang disajikan pada Gambar 1 .

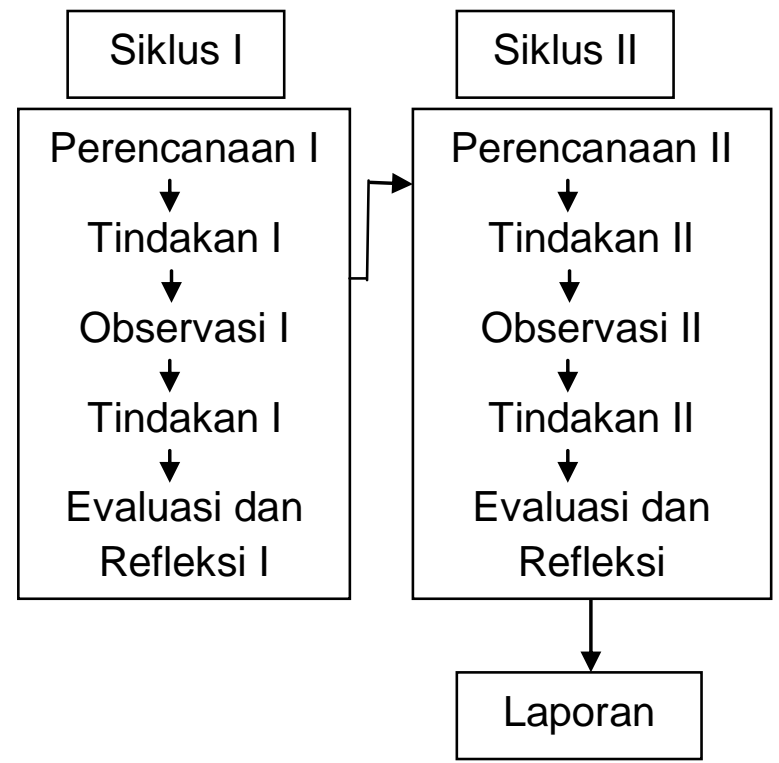

Gambar 1. Desain Pembelajaran PTK dengan model PjBL

Pada tahap perencanaan terdiri penyusunan instrument yang terdiri dari silabus, RPP, LKPD dan lembar bservasi. Selanjutnya tahap tindakan meliputi tahap implementasu kegiatan PTK yang diterapkan dalam lingkungan belajar di kelas. Selanjutnya tahap Observasi dimulai dari pengamatan pembelajaran selama dikelas sampai proses pembelajaran dikelas selesai. Tahap terakhir adalah evaluasi dan refleksi yang didalamnya terdiri dari mengevaluasi model pembelajaran yang telah diterapkan dan merefleksi apa saja kekurangan kekurangan yang ada selama proses pembelajaran yang akan di perbaiki pada siklus berikutnya.

Jenis data yaitu data kualitatif dan data kuantitatif. Data kualitatif diperoleh melalui observasi, menggunakan lembar observasi sedangkan data kuantitatif diperoleh melalui tes setiap akhir siklus tindakan. Data kualitatif dianalisis secara deskriptif kualitatif dan data kuantitatif dianalisis secara deskriptif kuantitatif. Deskriptif kualitatif yaitu penelitian yang menggambarkan atau melukiskan objek penelitian berdasarkan fakta- fakta yang tampak atau sebagaimana adanya. Dalam deskriptif kualitatif ini menggambarkan aktivitas guru dan siswa melalui lembar observasi. Sedangkan deskriptif kuantitatif adalah penelitian yang bertujuan menjelaskan fenomena yang ada dengan menggunakan angka-angka

\section{Hasil dan Pembahasan}

Berdasarkan hasil analisis diperoleh dua bentuk aktivitas selama proses PTK berlanhgsung yaitu aktivitas guru dan aktivitas siswa. Hasil analisis aktivitas di sajikan pada Tabel 1. 
Tabel 1. Rekapitulasi aktivitas guru pada siklus I dan siklus II

\begin{tabular}{|c|c|c|c|c|c|c|}
\hline \multirow{2}{*}{ No } & \multirow{2}{*}{\multicolumn{2}{|c|}{ Aspek yang di amati }} & \multicolumn{2}{|c|}{ Siklus I } & \multicolumn{2}{|c|}{ Siklus II } \\
\hline & & & P1 & $\mathbf{P 2}$ & P1 & P2 \\
\hline \multirow[t]{2}{*}{1} & \multirow[t]{2}{*}{ Penentuan proyek } & $\begin{array}{l}\text { Guru Memberikan pengarahan kepada } \\
\text { siswa tentang langkah-langkah model } \\
\text { pembelajaran Project Based Learning } \\
\text { (PjBL). }\end{array}$ & 1 & 1 & 1 & 1 \\
\hline & & $\begin{array}{l}\text { Guru menyuruh siswa menetukan } \\
\text { proyek pada materi pembelajaran yang } \\
\text { sedang di pelajari baik individu maupun } \\
\text { kelompok }\end{array}$ & 1 & 1 & 1 & 1 \\
\hline 2 & $\begin{array}{l}\text { perancangan } \\
\text { langka-langka } \\
\text { penyelesaian } \\
\text { proyek }\end{array}$ & $\begin{array}{l}\text { Guru merancang langkah-langkah } \\
\text { penyelesaian proyek. }\end{array}$ & 0 & 1 & 1 & 1 \\
\hline \multirow[t]{2}{*}{3} & \multirow{2}{*}{$\begin{array}{l}\text { penyusunan } \\
\text { jadwal } \\
\text { pelaksanaan } \\
\text { proyek }\end{array}$} & $\begin{array}{l}\text { Guru menyuruh siswa Menyusun jadwal } \\
\text { pelaksanaan proyek. }\end{array}$ & 1 & 1 & 1 & 1 \\
\hline & & $\begin{array}{l}\text { Guru memberikan LKS kepada siswa } \\
\text { berdasarkan materi yang di pelajari } \\
\text { dalam bentuk berkelompok. }\end{array}$ & 1 & 1 & 1 & 1 \\
\hline \multirow[t]{3}{*}{4} & \multirow{3}{*}{$\begin{array}{l}\text { penentuan proyek } \\
\text { dengan fasilitas } \\
\text { dan monitoring } \\
\text { guru }\end{array}$} & $\begin{array}{l}\text { Guru menyuruh siswa menyelesaikan } \\
\text { tugas proyek yang diberikan secara } \\
\text { berkelompok. }\end{array}$ & 0 & 1 & 1 & 1 \\
\hline & & $\begin{array}{l}\text { Guru memberikan fasilitator kepada } \\
\text { siswa }\end{array}$ & 1 & 1 & 1 & 1 \\
\hline & & $\begin{array}{l}\text { Guru monitoring siswa dengan cara } \\
\text { merekam aktivitas siswa pada saat } \\
\text { membuat proyek. }\end{array}$ & 0 & 1 & 1 & 1 \\
\hline \multirow[t]{2}{*}{5} & \multirow{2}{*}{$\begin{array}{l}\text { penyusunan } \\
\text { laporan dan } \\
\text { persentase } \\
\text { /publikasi hasil } \\
\text { proyek }\end{array}$} & $\begin{array}{l}\text { Guru kemudian menyuruh siswa } \\
\text { membuat hasil laporan. }\end{array}$ & 1 & 1 & 1 & 1 \\
\hline & & $\begin{array}{l}\text { Guru menyuruh siswa menyiapkan } \\
\text { persentasi didepan kelas berdasarkan } \\
\text { proyek yang sudah mereka buat. }\end{array}$ & 1 & 1 & 1 & 1 \\
\hline \multirow[t]{2}{*}{6} & \multirow[t]{2}{*}{$\begin{array}{l}\text { evaluasi proses } \\
\text { dan hasil proyek }\end{array}$} & $\begin{array}{l}\text { Guru memberikan kesimpulan terhadap } \\
\text { materi pembelajaran. }\end{array}$ & 0 & 0 & 1 & 1 \\
\hline & & $\begin{array}{l}\text { guru juga Mengevaluasi siswa dengan } \\
\text { cara memberikan tes kepada siswa. }\end{array}$ & 0 & 0 & 1 & 1 \\
\hline \multicolumn{3}{|c|}{ Jumlah } & 7 & 10 & 12 & 12 \\
\hline \multirow{2}{*}{\multicolumn{3}{|c|}{$\begin{array}{l}\text { Rata-Rata } \\
\text { Presentase }\end{array}$}} & \multicolumn{2}{|c|}{8,5} & \multicolumn{2}{|c|}{12} \\
\hline & & & \multicolumn{2}{|c|}{$71 \%$} & \multicolumn{2}{|c|}{$100 \%$} \\
\hline
\end{tabular}

Berdasarkan hasil observasi pada siklus I pertemuan pertama dan kedua, guru telah menerapkan model pembelajaran Project Based Learning (PjBL) sesuai dengan skenario pembelajaran yang telah dibuat agar pembelajaran berjalan dengan baik. Namun masih banyak kekurangankekurangan yang terjadi dalam proses pembelajaran siswa seperti banyak kebingungan dan kurang memerhatikan

saat

guru menjelaskan. Dari hasil observasi, ada beberapa kekurangan-kekurangan yang terjadi pada siklus I adalah sebagai berikut:

1. siswa kebingungan dan kurang memerhatikan saat guru menjelaskan.

2. Guru harus lebih memahami bagaimana penerapan model pembelajaran 
dengan menggunakan model pembelajaran Project Based Learning (PjBL)

3. Guru yang belum maksimal dalam memotivasi siswa serta, beberapa siswa yang ribut dan belum aktif untuk berani mengemukakan pendapatnya.

4. Siswa masih malu-malu pada saat tampil di depan kelas.

5. Guru harus menyimpulkan setiap akhir pembelajaran

Melihat dari hasil observasi siklus I (Tabel 1), maka perlu dilaksanakan refleksi dan perbaikan sebagai acuan dalam melaksanakan tindakan disiklus berikutnya. Pada pelaksanaan siklus II aktivitas mengajar guru dan siswa sudah baik dan sudah sesuai dengan langkah-langkah model pembelajaran Project Based Learning (PjBL) dan hasil dari tes yang diperoleh siswa sudah mencapai $80 \%$.

Sedangkan pada aspek aktivitas siswa disajikan pada Tabel 2.

Tabel 2. Rekapitulasi aktivitas siswa pada siklus I dan siklus II

\begin{tabular}{|c|c|c|c|c|c|c|}
\hline \multirow{2}{*}{ No } & \multirow{2}{*}{\multicolumn{2}{|c|}{ Aspek yang di amati }} & \multicolumn{2}{|c|}{ Siklus I } & \multicolumn{2}{|c|}{ Siklus II } \\
\hline & & & P1 & P2 & P1 & P2 \\
\hline \multirow[t]{2}{*}{1} & \multirow[t]{2}{*}{ Penentuan proyek } & $\begin{array}{l}\text { Guru Memberikan pengarahan } \\
\text { kepada siswa tentang langkah- } \\
\text { langkah model pembelajaran Project } \\
\text { Based Learnina (PiBL) }\end{array}$ & 1 & 1 & 1 & 1 \\
\hline & & $\begin{array}{l}\text { Guru menyuruh siswa menetukan } \\
\text { proyek pada materi pembelajaran } \\
\text { yang sedang di pelajari baik individu } \\
\text { maupun kelompok }\end{array}$ & 1 & 1 & 1 & 1 \\
\hline 2 & $\begin{array}{l}\text { perancangan langka- } \\
\text { langka penyelesaian } \\
\text { proyek }\end{array}$ & $\begin{array}{l}\text { Guru merancang langkah-langkah } \\
\text { penyelesaian proyek. }\end{array}$ & 0 & 1 & 1 & 1 \\
\hline \multirow[t]{2}{*}{3} & \multirow[t]{2}{*}{$\begin{array}{l}\text { penyusunan jadwal } \\
\text { pelaksanaan proyek }\end{array}$} & $\begin{array}{l}\text { Guru menyuruh siswa Menyusun } \\
\text { jadwal pelaksanaan proyek. }\end{array}$ & 1 & 1 & 1 & 1 \\
\hline & & $\begin{array}{l}\text { Guru memberikan LKS kepada siswa } \\
\text { berdasarkan materi yang di pelajari } \\
\text { dalam bentuk berkelompok. }\end{array}$ & 1 & 1 & 1 & 1 \\
\hline \multirow[t]{3}{*}{4} & \multirow[t]{3}{*}{$\begin{array}{l}\text { penentuan proyek } \\
\text { dengan fasilitas dan } \\
\text { monitoring guru }\end{array}$} & $\begin{array}{lll}\text { Guru menyuruh } & \text { siswa } \\
\text { menyelesaikan tugas proyek yang } \\
\text { diberikan secara berkelompok. }\end{array}$ & 0 & 1 & 1 & 1 \\
\hline & & $\begin{array}{l}\text { Guru memberikan fasilitator kepada } \\
\text { siswa }\end{array}$ & 1 & 1 & 1 & 1 \\
\hline & & $\begin{array}{l}\text { Guru monitoring siswa dengan cara } \\
\text { merekam aktivitas siswa pada saat } \\
\text { membuat proyek. }\end{array}$ & 0 & 1 & 1 & 1 \\
\hline \multirow[t]{2}{*}{5} & \multirow{2}{*}{$\begin{array}{l}\text { penyusunan laporan } \\
\text { dan persentase } \\
\text { /publikasi hasil proyek }\end{array}$} & $\begin{array}{l}\text { Guru kemudian menyuruh siswa } \\
\text { membuat hasil laporan. }\end{array}$ & 1 & 1 & 1 & 1 \\
\hline & & 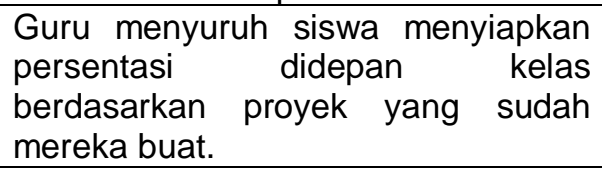 & & & & \\
\hline 6 & $\begin{array}{l}\text { evaluasi proses dan } \\
\text { hasil proyek }\end{array}$ & $\begin{array}{l}\text { Guru memberikan kesimpulan } \\
\text { terhadap materi pembelajaran. }\end{array}$ & 0 & 0 & 1 & 1 \\
\hline
\end{tabular}




\begin{tabular}{|c|c|c|c|c|c|}
\hline \multirow{3}{*}{ No } & \multirow{2}{*}{ Aspek yang di amati } & \multicolumn{2}{|c|}{ Siklus I } & \multicolumn{2}{|c|}{ Siklus II } \\
\hline & & \multirow{2}{*}{$\begin{array}{r}\text { P1 } \\
0\end{array}$} & \multirow{2}{*}{$\begin{array}{l}\mathbf{P 2} \\
0\end{array}$} & \multirow{2}{*}{$\begin{array}{l}\mathbf{P 1} \\
1\end{array}$} & \multirow{2}{*}{$\begin{array}{l}\mathbf{P 2} \\
1\end{array}$} \\
\hline & $\begin{array}{l}\text { guru juga Mengevaluasi siswa } \\
\text { dengan cara memberikan tes kepada } \\
\text { siswa. }\end{array}$ & & & & \\
\hline \multicolumn{2}{|r|}{ Jumlah } & 7 & 10 & 12 & 12 \\
\hline \multicolumn{2}{|r|}{ Rata-Rata } & \multicolumn{2}{|c|}{8,5} & \multicolumn{2}{|c|}{12} \\
\hline & Presentase & \multicolumn{2}{|c|}{$71 \%$} & \multicolumn{2}{|c|}{$100 \%$} \\
\hline
\end{tabular}

Berdasarkan Tabel 2 terlihat bahwa rata-rata aktivitas siswa mengalami peningkatan dari siklus 1 ke siklus 2 dengan persentasi rata-rata untuk siklus 1 yaitu $71 \%$ dan siklus 2 $100 \%$. Hal ini menunjukkan bahwa penggunaan model pembelajaran project based learning dapat meningkatkan aktivitas siswa selama proses pembelajaran. Selain itu penggunaan model pembelajaran project based learning dapat meningkatkan hasil belajara seperti yang disajikan pada Tabel 3 .

Tabel 3. Hasil analisis belajar siswa siklus I dan siklus II dengan menerapkan model pembelajar PjBL

\begin{tabular}{|l|c|c|}
\hline \multirow{2}{*}{ Pencapaian } & \multicolumn{2}{|c|}{ Siklus } \\
\cline { 2 - 3 } & $\mathbf{1}$ & $\mathbf{2}$ \\
\hline Jumlah Siswa (Orang) & 28 & 28 \\
\hline Nilai Tertinggi & 80 & 86 \\
\hline Nilai Terendah & 40 & 60 \\
\hline Nilai Rata-Rata & 71 & 77 \\
\hline$\%$ Tuntas & $64,2 \%$ & $85,7 \%$. \\
\hline$\%$ Tindak Tuntas & $35,7 \%$ & $14,2 \%$ \\
\hline
\end{tabular}

Berdasarkan hasil analisis pada Tabel 3 terhadap hasil belajar siswa dalam pelaksanaan penelitian pada tahun ajaran 2019/2020 dari siklus I ke siklus II, yakni pada siklus I terdapat 18 dari 28 siswa yang telah mencapai persentase ketuntasan klasikal sebesar $64,2 \%$ dan sisanya 10 siswa yang belum mencapai persentase ketuntasan klasikal sebesar $35,7 \%$ dengan nilai rata-rata hasil belajar siswa adalah 71 dari nilai KKM yang ditetapkan SDN 51 Kendari yaitu 70. Pada siklus II mengalami peningkatan yaitu terdapat 24 dari 28 siswa yang telah mencapai persentase ketuntasan klasikal sebesar 85,7\% dan sisanya 4 siswa yang belum mencapai persentase ketuntasan klasikal sebesar 14,2\% dengan nilai rata-rata hasil belajar siswa adalah 77 .

Berdasarkan uraian yang telah disajikan terlihat bahwa proses pembelajaran dengan menerapkan model pembelajaran Project Based Learning ( $\mathrm{PjBL}$ ) dalam penelitian ini, dikatakan mampu meningkatkan keaktifan setiap siswa dalam proses pembelajaran, menyelesaikan masalah dan saling bekerja sama, serta saling memberikan informasi kepada kelompok lain dan tingginya rasa tanggung jawab satu sama lainnya sehingga hasil belajar siswa dapat ditingkatkan, bukan saja kemampuan 
kognitifnya tetapi juga kemampuan afektif dan psikomotornya sehingga proses pembelajaran yang dilahirkan benar-benar mencerminkan pembelajaran yang efektif.

Selaij itu, berdasarkan hasil evaluasi pada siklus I terhadap hasil belajar siswa menunjukan bahwa dengan melaksanakan model pembelajaran Project Based Learning (PjBL) dapat meningkatkan hasil belajar siswa pada tema peristiwa dalam kehidupan di kelas VB SDN 51 Kendari jika dibandingkan dengan hasil belajar siswa pada tahun ajaran sebelumnya (2018/2019). Peningkatan hasil belajar siswa siklus I dapat dilihat pada Gambar 2.

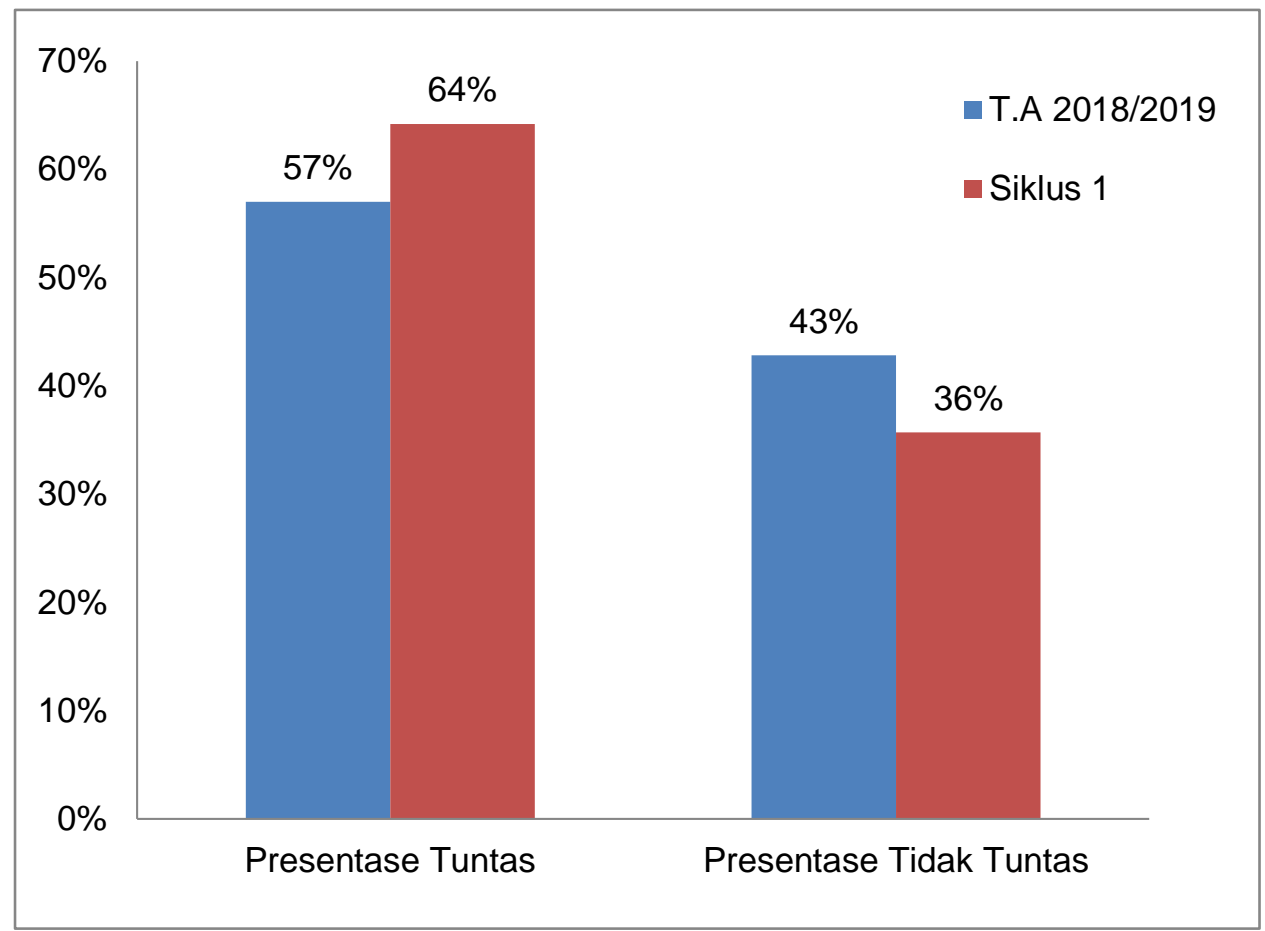

Gambar 2. Peningkatan hasil belajar siswa pada siklus I berdasarkan data awal sekolah

Berdasarkan Gambar 2 terlihat bahwa peningkatan hasil belajar siswa pada siklus I menunjukkan bahwa yang mencapai ketuntasan belajar pada siklus I berjumlah 18 orang siswa dengan persentase sebesar $64,2 \%$ sedangkan, jumlah 10 siswa yang tidak tuntas dengan persentase sebesar $35,7 \%$ dengan nilai rata-rata 71 . Maka,hasil belajar siswa belum mencapai ketuntasan belajar. Meskipun hasil belajar siswa secara klasikal meningkat namun belum memenuhi indikator kinerja sebesar $80 \%$.

Kemudian peningkatan hasil belajar siswa meningkat pada siklus II untuk lebih jelasnya peningkatan hasil belajar siswa dapat dilihat pada Gambar 2 berikut. 


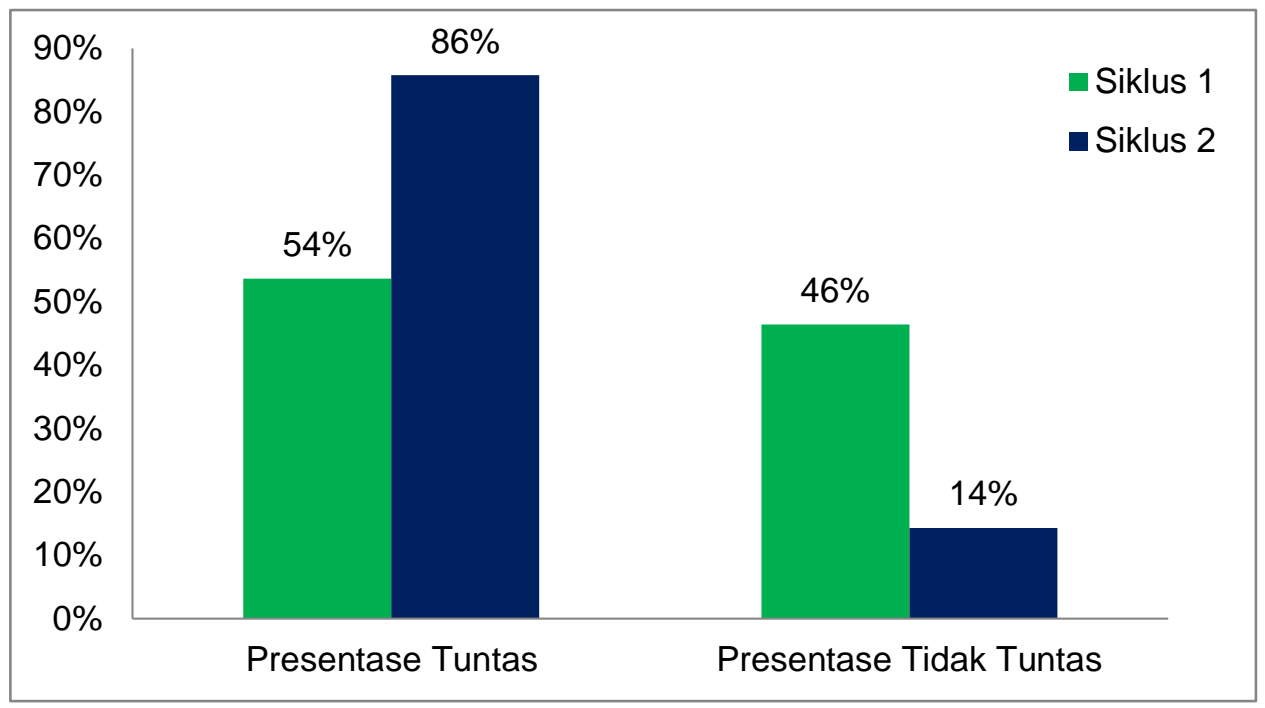

Gambar 3. Peningkatan hasil belajar siswa pada tiap siklus

Berdasarkan Gambar 3 diperoleh bahwa penerapan model PjBL pada siklus II dapat dikatakan meningkat atau mencapai keberhasilan karena dari beberapa aspek dalam pembelajaran yang dilaksanakan oleh guru, hampir tercapai sepenuhnya serta keaktifan siswa dalam berdiskusi lebih meningkat dibandingkan dari siklus sebelumnya.

Siklus II mengalami peningkatan yaitu terdapat 24 dari 28 siswa yang telah mencapai persentase ketuntasan klasikal sebesar $85,7 \%$ dan sisanya 4 siswa yang belum mencapai persentase ketuntasan klasikal sebesar $14,2 \%$ dengan nilai rata-rata hasil belajar siswa adalah 77 dari nilai KKM yang ditetapkan SDN 51 Kendari yaitu 70 . Dengan melihat hasil belajar siswa yang telah mencapai Kriteria Ketuntasan Minimal (KKM) yang ditetapkan oleh SD Negeri 51 Kendari yaitu 70. Rusman, (2018) berbendapat bahwah hasil belajar terjadinya karena adanya perubahan tingkah laku pada diri siswa yang dapat diamati dan diukur dalam bentuk perubahan pengetahuan, sikap dan keterampilan. Perubahan tersebut dapat diartikan terjadinya peningkatan dan pengembangan yang lebih baik dibandingkan dengan sebelumnya, misalnya dari tidak tahu menjadi tahu, sikap kurang sopan menjadi sopan dan sebagainya.

Berdasarkan uraian di atas, maka proses pembelajaran dengan menerapkan model pembelajaran Project Based Learning (PjBL) dalam penelitian ini, dikatakan mampu meningkatkan keaktifan setiap siswa dalam proses pembelajaran, menyelesaikan masalah dan saling bekerja sama, serta saling memberikan informasi kepada kelompok lain dan tingginya rasa tanggung jawab satu sama lainnya sehingga hasil belajar siswa dapat ditingkatkan, bukan saja kemampuan kognitifnya tetapi juga kemampuan afektif dan psikomotornya sehingga proses pembelajaran yang dilahirkan benar-benar mencerminkan pembelajaran yang efektif. Sejalan dengan itu pula Menurut John Thomas 
tujuan dari model Project Based Learning adalah memberikan pembelajaran yang bersifat tugastugas kompleks, yang didasarkan pada pertanyaan/masalah menantang, yang melibatkan siswa dalam mendesain, memecahkan masalah, membuat keputusan atau kegiatan investigasi, memberikan siswa kesempatan untuk bekerja secara mandiri selama periode lama dan berujung pada realistis produk atau presentasi (Rusman, 2015).

Dengan demikian, penerapan model pembelajaran project based learning pada tema Peristiwa Dalam Kehidupan di kelas VB mengalami peningkatan karena telah mencapai indikator keberhasilan yaitu $80 \%$.

\section{Kesimpulan}

Berdasarkan hasil penelitian dan pembahasan maka dapat disimpulkan bahwa penggunaan model pembelajaran project based learning (PjBL) pada Tema Peristiwa Dalam Kehidupan di kelas VB SD Negeri 51 Kendari dapat meningkatkan hasil belajar siswa karena: dari hasil observasi awal pada semester II tahun ajaran 2018/2019 kelas VB SDN 51 Kendari, dari total 28 siswa di kelas VB hanya 12 siswa $(42,8 \%)$ yang telah mencapai nilai KKM sedangkan 16 siswa $(57,1 \%)$ belum mencapai nilai KKM. Sedangkan peningkatan hasil belajar siswa dalam pelaksanaan penelitian pada tahun ajaran 2019/2020 dari siklus I ke siklus II, yakni pada siklus I terdapat 18 dari 28 siswa yang telah mencapai persentase ketuntasan klasikal sebesar $64,2 \%$ dan sisanya 10 siswa yang belum mencapai persentase ketuntasan klasikal sebesar $35,7 \%$ dengan nilai rata-rata hasil belajar siswa adalah 71 dari nilai KKM yang ditetapkan SDN 51 Kendari yaitu 70. Pada siklus II mengalami peningkatan yaitu terdapat 24 dari 28 siswa yang telah mencapai persentase ketuntasan klasikal sebesar $85,7 \%$ dan sisanya 4 siswa yang belum mencapai persentase ketuntasan klasikal sebesar 14,2\% dengan nilai rata-rata hasil belajar siswa adalah 77 dari nilai KKM yang ditetapkan SDN 51 Kendari yaitu 70. Oleh karena itu, pada siklus II telah mencapai indikator keberhasilan sebesar $80 \%$ dari jumlah siswa seluruhnya maka dapat dikatakan penelitian ini dapat meningkatkan hasil belajar siswa SD Negeri 51 Kendari. Untuk peneliti selanjutnya yaitu sebaiknya memperhatikan situasi dan penggunaan waktu selama proses pembelajaran agar efektif dan efisien .

\section{Daftar Pustaka}

Efrimal, F., Kurnia , K., \& Wasidi. (2017) Penerapan Model Project Based Learning (Pjbl) Untuk Meningkatkan Kecermatan dan Kreasi Seni Rupa (Studi Pada Siswa Kelas XI SMA Negeri 3 Seluma). DIADIK : Jurnal IImiah Teknologi Pendidikan. 7(2), 48-61

Hapsari, D. I., \& Airlanda, G. S. (2019). Penerapan project based learning untuk meningkatkan motivasi belajar matematika. Jurnal Riset Teknologi dan Inovasi Pendidikan (JARTIKA), 2(1), 102-112. 
Herawati, R., Sulisworo, D., \& Fayanto, S. (2019). The Development of Learning Videos on PowToon-based Work and Energy Topics to Support Flipped Classroom Learning. IOSR Journal of Research \& Method in Education, 9(4), 51-58.

Jakni. (2017). Penelitian Tindakan Kelas (PTK). Bandung : Alfabta.

Kawuri, M. Y. R. T., Ishafit, I., \& Fayanto, S. (2019). Efforts to improve the learning activity and learning outcomes of physics students with using a problem-based learning model. IJIS Edu: Indonesian Journal of Integrated Science Education, 1(2), 105-114.

Kawuri, M. Y. R. T., \& Fayanto, S. (2020). Penerapan Model Discovery Learning Terhadap Keaktifan dan Hasil Belajar Siswa Kelas X MIPA SMAN 1 Piyungan Yogyakarta. Jurnal Penelitian Pendidikan Fisika, 5(1), 1-8.

Lase, D. (2019). Education and Industrial Revolution 4.0. Jurnal Handayani PGSD FIP UNIMED, 10(1), 48-62.

Notanubun, Z. (2019). Pengembangan Kompetensi Profesionalisme Guru di Era Digital (Abad 21). Jurnal Bimbingan dan Konseling Terapan, 3(2), 54-64.

Rusman.(2015). Pembelajaran Tematik Terpadu. Jakarta : Rajawali pers.

Riyanto, H. Y. (2014). Paradigma Baru pembelajaran: Sebagai referensi bagi pendidik dalam Implementasi Pembelajaran yang Efektif dan berkualitas. Prenada Media.

Rusman. (2017). Belajar Dan Pmbelajaran Beroriantasi Standar Proses Pendidikan. Jakarta: Predana Media Group.

Sari, D. P. (2017). Meningkatkan Kreativitas Belajar Siswa Menggunakan Model Pembelajaran Project Based Learning Pada Mata Pelajaran IPA Di Kelas VB SD Negeri 34/I Teratai. Skripsi Program Studi Pendidikan Guru Sekolah Dasar, Jurusan IImu Pendidikan, FKIP Universitas Jambi.

Sunardin, S. (2019). Peningkatan Hasil Belajar Siswa Pada Pembelajaran IPS melalui Penerapan Model Project Based Learning. Indonesian Journal of Educational Studies, 21(2).

Surya, A. P., Relmasira, S. C., \& Hardini, A. T. A. (2018). Penerapan model pembelajaran project based learning (PjBL) untuk meningkatkan hasil belajar dan kreatifitas siswa kelas III SD Negeri Sidorejo Lor 01 Salatiga. Jurnal Pesona Dasar, 6(1).

Susanto, A. (2014). Pengembangan pembelajaran IPS di SD. Jakarta: Kencana 